\title{
Apple Flavor
}

National Cancer Institute

\section{Source}

National Cancer Institute. Apple Flavor. NCI Thesaurus. Code C73362.

A characteristic of a medicinal product, specifying that its most predominant agreeable savor detected by the unified sensation of taste and olfactory receptors resembles apple. 